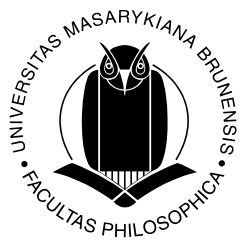

Brno Studies in English

Volume 43, No. 1, 2017

ISSN 0524-6881

DOI: $10.5817 /$ BSE2017-1-9

Bożena KuCAŁa

\title{
Penelope Lively's Autobiographical Memory
}

\begin{abstract}
This article examines the concept of memory in three autobiographical books by Penelope Lively: Oleander, Jacaranda: A Childhood Perceived (1994), A House Unlocked (2001) and Ammonites and Leaping Fish: A Life in Time (2013). As a novelist, Lively has a special interest in the ways in which people engage with the past, both private and collective. There are noticeable correlations between her fictional and non-fictional pronouncements on history and memory. The article emphasises the writer's conviction that memory is crucial to both her own and a collective sense of identity. By referencing three autobiographies, it further demonstrates how, without invoking any particular theory, Lively implicitly relies on diverse models of memory. These models range from a palimpsest or a storehouse of ideas to layers of archaeological evidence. Finally, the writer's refusal to narrativise her memories is treated as an expression of her acknowledgement of the contingency of memory, and as an assertion of her awareness of the potential for distortion inherent in historical narratives.
\end{abstract}

Key words

Penelope Lively; autobiography; memory; history; identity

As a novelist, Lively has made "the presence of the past" (Lively 2014: 173) one of the abiding concerns of her fiction, acknowledging its continuing influence on and interaction with the present, whether in private life or collective history. ${ }^{1}$ In an interview for Publisher's Weekly in 1988 the writer declared:

I am extraordinarily interested in history [...] worried about how a lot of people don't realize that history is true, that it has actually happened $[. .$. Perhaps what I am interested in even more is the operation of memory in every possible sense, the way in which both people and landscape are 
composed of memory, the ways in which the physical world is composed of memory. (qtd. in Blom 1997: 240)

Lively's interest in history and memory goes back to her university days - the future writer read history at Oxford. As she explained in another interview: "The experience of learning about history and the ways in which it's discussed kindled my interest in memory. It didn't make me a novelist, but it very much conditioned the kind of novels I've written" (Lively 2009). One can easily detect parallels between Lively's own opinions and some of her characters' views. For example, the protagonist of According to Mark (1984) clearly shares his creator's commitments: "It sometimes seemed to Mark impossible that the historic past was extinguished, gone; surely it must simply be somewhere else, shunted into another plane of existence, still peopled and active and available if only one could reach it" (Lively 1985: 110). Likewise, the historian-narrator of Lively's 1987 Booker Prize-winning novel Moon Tiger is, in the words of Frans Blom, "a successful medium for [the writer's] ideas about history and memory" (1997: 241). ${ }^{2}$ Boyd Tonkin resorts to an archaeological metaphor to describe Lively's constant preoccupations: "her fiction has dug deep into the mingled strata of memory, imagination and documentary record that compose the stories we tell ourselves and others" (Tonkin 2013).

The writer covers the same ground in her non-fiction. Her three autobiographical books, Oleander, Jacaranda: A Childhood Perceived (1994), A House Unlocked (2001) and Ammonites and Leaping Fish (2013), ${ }^{3}$ are a testimony to the crucial role of memory in connecting an individual to her past. All of these books, in which the writer tries to recollect the experiences of her younger self, offer a practical demonstration of the processes of memory and convey the results of Lively's retrieval of her own past. The latest one, however, exposes the drive behind the entire autobiographical project by devoting a separate chapter to memory. In Ammonites and Leaping Fish, the retrospection is suffused with the writer's reiterated belief that it is thanks to memory that we have a sense of selfhood; it is also memory that enables us to inscribe our lives in the larger patterns of collective history. Ammonites and Leaping Fish, written from the perspective of an octogenarian, is subtitled A Life in Time. Lively emphasises that "The mind needs its tether in time, it must know where it is - in the perpetual slide of the present, with the ballast of what has been and the hazard of what is to come" (Lively 2014: 123). For all its deficiencies, memory is indispensable to the formation and sustenance of individual identity: "Autobiographical memory is random, nonsequential, capricious, and without it we are undone" (Lively 2014: 122).

As a writer with an academic background in the study of history and a private commitment to archival research, Lively is acutely aware of the ongoing changes that affect individuals and communities, families and nations, landscapes and cities. Now, personally afflicted by time and confronted with transience ("in old age I am time made manifest" [Lively 2014: 158]), the writer asserts the importance of memory as the only reliable safeguard against this constant mutability: 
"[Time] sweeps us along, the ever-rolling stream and all that, nothing to be done about it, but we do have this one majestic, sustaining weapon, this small triumph over time - memory" (Lively 2014: 158). Lively's autobiographical books encapsulate her victory over time by recording the residue of the past in her mind.

In Borderlines: Autobiography and Fiction in Life Writing, Gunnthórunn Gudmundsdóttir points out that "autobiography is essentially the genre of memory" and therefore "It is not only the memories themselves that are the autobiographer's subject, but also memory itself and the process of remembering" (2003: 11-12). Lively's recollections in the three books are interspersed with numerous overt reflections on memory. Without explicitly endorsing any particular model, she restates her strong belief in its relevance and conveys her intuitive understanding of how it works. Yet the observations she shares with the reader do reveal a certain approach, which, although neither methodical nor entirely consistent, may be ascertained by analysing her pronouncements and her writing practice. Based on her autobiographical writing, the aim of this paper is to attempt a comprehensive account of Lively's concept of memory.

\section{"We are all of us palimpsests"}

In stressing the role of memory as the main constituent of identity, Lively affirms from her private perspective a widely-accepted claim about the interconnectedness of memory and identity that dates back to the beginning of the early modern era. In An Essay Concerning Human Understanding, John Locke posited that our sense of identity depends on the continuity of consciousness, which in turn is made possible by the retention of ideas in our mind. Locke affirms that "consciousness, as far as ever it can be extended - should it be to ages past - unites existences and actions very remote in time into the same person" (1894: 458). He defines "person" as "a thinking intelligent being, that has reason and reflection, and can consider itself as itself, the same thinking thing, in different times and places" (1894: 448).

In her most recent autobiographical book, Lively foregrounds the cohesive and integrative function of memory. There, naturally, her retrospective covers the widest array of her different "selves." With a considerable degree of overlap, all of her autobiographical writings reference her childhood in Egypt, her transition to England at the end of the Second World War, her adolescent years spent alternately in London and in her grandmother's country house in Somerset, her school and university days, her marriage, motherhood, writing career and present senility. Taking advantage of "the long view" accessible to a person of her age, she reviews "varieties of [her]self" 4 while affirming her belief in a "signature identity" that is immune to the mutations wrought by time: "The body may decline [...], but the mind has a healthy continuity, and some kind of inbuilt fidelity to itself, a coherence over time" (2014: 41-42). For all the diverse imprints that time leaves on the mind, the mind remains the same. 
Equipped with a historian's mode of perception, Lively sees no contradiction between sameness and mutability because her notion of human identity rests on the idea of an unbroken thread linking different stages of life. Moreover, from Lively's point of view, continuity is a principle which determines not only personal identity; indeed, all that exists in the present bears the marks of its past. Freely shifting from personal recollections to generalisations, the writer insistently exposes the layers of the past which underlie what we see today in social mores and institutions, global history and politics, gardens and landscapes. Analogies are drawn between the material traces of the past and the residue it has left in the human mind. This leads her to claim that, just as the physical English landscape is a palimpsest in which evidence of previous ages can still be detected, "We are all of us palimpsests; we carry the past around" (Lively 2014: 174).

In his essay "A Note upon the "Mystic Writing Pad" (1925) Freud famously conceptualised the memory process by reformulating the old metaphor of inscription with its provenance in Plato's model of memory as a wax tablet on which our perceptions and ideas are impressed. ${ }^{5}$ Freud's modification of the model entails a doubling of the imaginary writing surface. Referring to the mystic writing pad device, Freud expounds on the supposed functioning of memory. He assumes the existence of two layers: the covering celluloid sheet from which the writing disappears as soon as the sheet has been lifted, and the slab underneath which preserves permanent traces of what has been written. In Freud's model, "our mental apparatus [...] has an unlimited receptive capacity for new perceptions and nevertheless lays down permanent - even though not unalterable - memory-traces of them" (Freud 1959: 176). The upper and lower layers relate, respectively, to Freud's notion of the conscious mind and the unconscious (cf. Rossington and Whitehead 2007: 94).

Whereas Lively does not embrace the Freudian binarism of the conscious and the unconscious, her concept of memory is indebted to his idea of partial erasure and constant re-inscription. Frequently remarking on the fragmentariness of what she remembers, the writer nevertheless states that "we are each of us the accretion of all that we have been" (Lively 2014: 57). Lively's own sense of identity depends on the accumulation of experiences over the years. Her grandmother's country house in Somerset is remembered as one of the formative places in her life; it is a place that she visited in her childhood and youth, and which she now frequently recollects: "each return to the place now safely stashed away in the mind, intact and inviolate, I review the familiar landscape of the house" (Lively 2001: 195). Thus, the original memories of her visits are constantly renewed or re-inscribed thanks to the process of recollection. The writer reflects on the inevitable dichotomy between her memories and her primary impressions by stressing that "Today, the continuous present of the late 1940s is overlaid by re-interpretations" (2001: 202). The split between her younger, experiencing self, and the older self who remembers, comments and records it in writing, corresponds to the layered structure of the writer's memory. ${ }^{6}$

The "double vision" which shapes Lively's recollections in A House Unlocked (Lively 2001: 202) is also the organising principle of her first autobiographical 
piece, Oleander, Jacaranda. The book intertwines two accounts: the first is of the future writer's childhood in Egypt, and the second is of her journey to the same place forty years later. The effect of the visit is a palimpsest-like image of herself and also of the Egyptian setting in which she grew up. Oleander, Jacaranda combines Lively's present experiences with the memories and associations evoked by her visit. The house in which she used to live looks different now, but its original version still exists in her mind and is inhabited by a ghostly version of her childhood self ("there was also the powerful feeling that on some other plane of existence the Ur-house was still there also, [...] and I with it" [1995: 8]).

In her book Memory, Narrative, Identity: Remembering the Self Nicola King points out that "In everyday social discourse, and in much conventional autobiography, these narratives [of the past] tend to elide memory as a process: the content is presented as if it were uniformly and objectively available to the remembering subject, as if the narrating 'I' and the subject of narration were identical" (2000: 3 ). This is patently not the case in Lively's book. Her memories of her childhood and of her later visit are predicated on her awareness of the processes of memory. Consequently, her present vision, informed by knowledge and experience, coexists and contrasts with her juvenile perceptions, causing her to be split into different selves: "I $[\ldots]$ perceived with excitement the chasm between past and future, the perpetual slide of the present. As, writing this, I think with equal wonder of that irretrievable child, and of the eerie relationship between her mind and mine" (Lively 1995: 1).

The idea that remembering entails the appearance of mental images ("phantasmata") goes back to Aristotle. Aristotle's observations led him to the conclusion that, in the words of David Farrell Krell, "Remembrance instigates a peculiar kind of presence. [...] For while remembering, a man tells himself that he is now present to something that was earlier" (1990: 15-16). This particular presence of the past is Lively's experience during her visit. Her younger self is not always a stranger; in fact, throughout the text the pronoun "I" repeatedly shifts between the two Penelopes, as if she were mentally transported back to her childhood; this device is mirrored by her frequently shifting to the present tense when narrating the past.

The layers proliferate: superimposed upon the childhood memories in her head are the recent memories of her visit, photographs, letters and her acquired historical expertise. Nor is there a clear-cut division between the different kinds of script in the writer's mind (to use the Freudian metaphor): "I can turn the cold eye of adult knowledge and experience upon the moment and interpret it in the light of a lifetime's reading and reflection. But what seems most astonishing of all is that something of the reality of the moment survives this destructive freight of wisdom and rationality" (Lively 1995: 2). Apparently, some of the initial memory traces are still legible, despite the obfuscating strata of later knowledge. As in a palimpsest, these initial traces may even displace the later imprints. Looking back is compared to peering into a mist which envelops "dim shapes and impressions" (1995: 160), but now and again certain scenes or images from the past leap 
into clarity, prompted either by a conscious effort of recollection, a confrontation with the physical remains of the past, or involuntary sensory stimuli.

\section{Archaeology, archives and artefacts}

Lively's notion of memory as a palimpsest is based on the definition of a palimpsest as a multi-layered record, but she tends to depart from the customary conceptualisation of the palimpsest as a flat writing surface. Instead, in her view, the different strata seem to form a spatial structure, in which sediments of the past are deposited in a manner that can be likened to archaeological evidence.

As King notes, it is impossible to speak about memory without resorting to metaphor (2000: 25). John Locke defined memory as "the storehouse of our ideas" (1894: 193); related to his metaphor are concepts that envisage memory as a collection of images or imprints on the brain, an archive, or some other kind of storage space (cf. Kalaga 2012: 80). In his explorations of the processes of memory, Freud used the model of the mystic writing pad to explicate the relations between the conscious and the unconscious, but he also relied on an archaeological analogy to describe the process of uncovering concealed or repressed memories. In Studies on Hysteria, Freud presented the treatment of this condition in terms of archaeological excavation: "This procedure was one of clearing away the pathogenic psychical material layer by layer, and we liked to compare it with the technique of excavating a buried city" (qtd. in King 2000: 12).

For Lively, who obviously approaches the question of memory from a very different angle, the retrieval of buried memories carries no such distressing implications. In her autobiographies, the idea of archaeological evidence serves both as a metaphor for memories and, when understood literally, provides a solid link to the past. A visit to an archaeological dig outside Cairo triggered one of the epiphanic moments of her childhood: "I stand there enthralled, glimpsing time, and death [...] The moment appears seminal" (Lively 1995: 68). In Ammonites and Leaping Fish the writer professes: "Archaeology appeals to me precisely because it offers tacit but tangible evidence - the pots, the weapons, the bones, the stones" (2014: 138). As a self-styled "archaeologist manquée," Lively has even carried out some amateur archaeological work in and around the houses in which she has lived (2014: 232). Accordingly, the deposits of memories in her mind are often described in analogous terms to material sediments: she retains "shreds" of her foreign travels (2014: 29, 104), "shreds" of the literature she has read, "assorted shards" of childhood (2014: 127); "Our early assumptions and beliefs are archaeological debris" (2001: 214). She attempts to "uncover" (1995: viii), "recover" (1995: 83), "retrieve" (1995: 2) the past, "forag[e] among the shards in [her] head" (1995: 146), "take the shards within [her] head and try to place them within the correct strata" (1995: 51).

Evoking scenes from her life, Lively emphasises the fragmentariness, randomness and dislocation of these memories, while remarking that the rest has been 
lost. The selected remnants of the past that we carry in our heads are a result of the operation of the laws of memory, which remain quite opaque. "We forget - we forget majestically - and that seems to be an essential part of memory's function," reflects Lively (2014: 124) while wondering at the arbitrariness of what our memory chooses to forget or, conversely, to retain. As in archaeological work, the results of the process of retrieval are uncertain, and this is something she frequently comments on in relation to her own autobiographical project. Some images from the past are firmly fixed and can be evoked at will, others must be recovered by means of material objects and written records, others still come to the surface of their own accord thanks to associations or sensory impressions. Yet there remain, buried in the layers of the past, large chunks of experience which seem completely unmarked by evidence and thus irrevocably lost. Particularly when analysing her earliest memories, Lively has to confront the temporal distance between her knowing, mature perspective and the vision and limited knowledge of the child that she was. As Maggie Traugott says in her review of Oleander, Jacaranda, "Even if Lively concedes that you can't scientifically quantify the extraordinary way children learn to negotiate the jungle in which they find themselves, she has a go, by means of grown-up methodology and metaphor"; Traugott traces Lively's methodology and metaphor to archaeology (Traugott 1994). ${ }^{7}$ Peter Parker makes the same observation when he describes Ammonites and Leaping Fish as "certainly archaeological in its method, digging down into the past to turn up shreds that provide a fragmentary but fascinating portrait not only of the author but of the times through which she has lived" (Parker 2013).

The archaeological analogy corresponds to the spatial models of memory detectable in Lively's writings, which take the shape of a storage space or a container: memory is compared to a cabinet (2014: 132), a cupboard (2014: 136), a hoard (2014: 137), a larder (2014: 137), a vessel (2014: 161). Her memory also functions as a private archive: "pictures in the mind" (1995: viii), an "assemblage of slides in the head" (1995: 49), or a "virtual library in the head - the floating assemblage of fragments and images and impressions and information half-remembered" (2014: 184).

Heller McAlpin rightly says that Lively's approach to autobiography is "more archaeological than chronological, more historical than personal and more analytic than emotional" (McAlpin 2014). In all the three books considered here, the writer is determined to align her memory with collective history, for which she needs external evidence. Therefore, Lively has supplemented her personal recollections with extensive reading. In Oleander, Jacaranda her memories of Egypt are recounted in tandem with the results of her archival research. Her childhood was concurrent with the last years of the British presence in Egypt, the last years of Empire and the military campaigns in North Africa during the Second World War. Yet she had little knowledge or understanding of it at the time. Now she tries to contextualise her childhood encounters with history by reading books, watching films and examining photographs (1995: 52). Consequently, besides the writer's own life and opinions, Ammonites and Leaping Fish covers a variety 
of topics: history and politics, long-term changes in class hierarchies, old age as a social phenomenon, etc. Lively admits to an addiction to reading: "Old reading, revisiting, but new reading too, lots of it, reading in all directions, plenty of fiction, history and archaeology always, reading to satisfy perennial tastes, reading sideways too - try her, try him, try that, Amazon and AbeBooks would founder without me; my house is a book depository" (2014: 35). She has amassed an extensive private library which has "an archival aspect": her books speak for their owner and the library is in effect "autobiographical" (2014: 185-187).

That early moment of illumination at the archaeological dig in Egypt taught Lively to value the material evidence of history. Throughout her autobiographical writings, she emphasises the potential for objects to evoke the past and testify to its reality. The last chapter of Ammonites and Leaping Fish is a celebration of six things - tangible, material objects that have been endowed with meaning by their owner: "My house has many things, too, besides those books - the accretion of a lifetime" and "they articulate something of who I am" (2014: 199).

A House Unlocked offers a far more substantial antecedent for Lively's analysis of how certain objects may function as a kind of "material memoir" (2014: 200). Cressida Connolly summarises the book as "part memoir, part social history, a curious and mostly engaging hybrid in which events of the twentieth century are extrapolated from objects in the house. It's not so much Speak, Memory as 'Speak, Picnic Rug'" (Connolly 2001). ${ }^{8}$ The concept of the book is derived from mnemonic systems going back to antiquity, in which memory is treated as "an art or craft, a series of learned techniques that can enhance natural ability" (Richards 2007: 22). The anonymous author of Ad Herennium, a foundational text for ancient accounts of rhetorical memory, advises the orator who wishes to train his memory to create a spatial background for storing images, preferably an architectural construct: "for example, a house, an intercollumnar space, a recess, an arch, or the like" (qtd. in Rossington and Whitehead 2007: 44). This imaginary structure may subsequently be used for the mental placement of the things one needs to memorise and then retrieve. ${ }^{9}$

Lively's immediate inspiration for A House Unlocked was Frances A. Yates's book on the art of memory from antiquity to early modernity. ${ }^{10}$ However, at this stage in her life, Lively is only interested in one side of the art of memory - not how to memorise but how to reconstruct the past. In the Preface to A House Unlocked, the writer explains which aspect of the tradition she found useful in her recollections:

Frances Yates's fine book [...] describes the system whereby [...] the orator moved from room to room [of an imaginary mansion], each space serving as a stage in the argument, and the emotive trappings - a statue, an urn, a painting - acting as prompts for specific flights of language.

In the same way, I can move around my memory house and focus upon different objects. The house itself becomes a prompt - a system of reference, as assemblage of coded signs. (2001: $\mathrm{x})$ 
Yates comments that "The classical sources seem to be describing inner techniques which depend on visual impressions of almost incredible intensity" (1999: 19). Such also seems to be the quality of Lively's recollections; she invariably begins each section of her book with a detailed description of objects, most of which are out of her sight. Her "memory house," her mnemonic locality, is recollected rather than imagined - Lively mentally reconstructs Golsoncott, her grandmother's family home.

Kathy Mezei argues that domestic spaces play "a crucial yet often unacknowledged part" in endowing biography and autobiography with vividness and authenticity. But she goes on to stress that, besides providing the context for the private lives that are lived within the house and home, domestic spaces are also "the product of a society, they express and reinforce its norms, social practices, and ideologies" (2005: 81). In her recollections of Golsoncott, Lively consistently forges connections between the private and the public. The place was the backdrop to important events in the writer's own life but also, as she argues, reflected English and European history in the twentieth century. The design for the book rests on the conceit of taking an imaginary tour of the house and stopping by several objects which function as memory prompts: "The chairs and tables and rugs and pictures and knick-knacks [...] conjure up other times and other places and people no longer alive" (2001: 89). These artefacts have the power to set in motion a wide-ranging train of association. For example, the gong stand in the hall and the copy of The Book of Common Prayer on top of it are reminders of family rituals, communal church-going, the erosion of religion in post-war England and the issue of architectural heritage. Thus, the objects which once furnished her family house have the capacity to generate entire scenes, mini-stories as well as historical explication.

\section{“... but I am not writing history"}

King notes that in addition to the popular idea of memory as a "storehouse of experiences," the other dominant and distinct way of imagining memory involves "a form of language or narrative" (2000: 25). Narrativisation obviously entails interpretation and revision, the translation of imprints in the mind into a story. For experience to be reconstructed as a life history, it must be polished into a literary pattern. In "Narrative Identity" Paul Ricoeur claims that "we ordinarily speak of life as a story" (1991: 77); life stories become more intelligible when rendered in the manner of narrative models borrowed from fiction and history, of which autobiography is a convincing illustration (1991: 73). Ricoeur makes three interrelated claims, linking history, fiction and autobiography:

a) knowledge of the self is an interpretation; b) the interpretation of the self, in turn, finds narrative, among other signs and symbols, to be a privileged mediation; c) this mediation borrows from history as much as fiction making 
the life story a fictive history or, if you prefer, an historical fiction, comparable to those biographies of great men where both history and fiction are blended together. (1991: 73)

Gudmundsdóttir observes the prevalence of narrative structure in autobiographies and comments that it is "of prime importance for the way in which the autobiographer establishes causality and meaning in his or her life-story" (2003: 60). As a writer situated at the intersection of literature and history, Lively acknowledges the narrative potential of her memories. Her retrieval of the past in her first autobiographical book begins with the "frozen moments" (1995: vii) stored in her mind. Lively stresses that for her as a child growing up in Egypt, "there was no narrative - just the compelling immediacy of life." It was much later, when she acquired "adult habits of mind," that she began to perceive her experience as part of the narrative of history (1995: 63). Her awareness of the allure of the narrative mode is especially evident in the last of her three autobiographical books. The desire for narrative is propelled by the sense of an ending, something that is inevitably felt by a person of her age. In Lively's words, everyone is "attuned to the idea of life as a narrative" (2014: 22). The view from the vantage point of old age is especially "affected by the habits of fiction" (2014: 24), whereby we attempt to impose explanatory patterns upon the actual unruliness of life. A similar operation is at work in collective memory. For Lively, the Blitz serves as an example of the inevitable subjugation of contingent reality to historical narratives; from the immediacy and chaos of the initial experience, the event "has slipped off into history, into the books, into the documentaries and the fictional reconstructions. It has spun its own legends" (2014: 76). Narrative is inescapable but narrative inevitably distorts what happened. Over a longer time span patterns and trends are revealed, which, in turn, overshadow the contingent and the particular. In her article "Bones in the Sand" Lively discussed the dialectic between a private and a collective past in her fiction: "the revelation that there is a collective past is the revelation also that that collective past is composed of myriad private pasts, that the pursuit of social memory is matched by the need for personal memory" (Lively 1981: 650).

Writing her autobiographical books has obliged Lively to balance conflicting tendencies in her approach to memory. On the one hand, her background in the study of history prompts her to see her life as part of the unfolding, large-scale process of historical change: "If you have no sense of the past, no access to the historical narrative, you are afloat, untethered; you cannot see yourself as a part of the narrative" (2014: 137). Furthermore, at a personal level, the novelist in her "wants shape and structure, development, a theme, insights" (2014: 125). Yet she deliberately stops short of converting her assortment of memories into a life story, since this would affect the veracity of her account. She makes no great claims for the explanatory potential of her memories ("but I am not writing history - I am trying to sort out what I know now happened" [2014: 84]). Hence, in an attempt to save her recollections from distortion, her autobiographical books 
defy chronology and refuse to conform to narrative patterns. It may be relevant here to note that the aged narrator of Lively's most recent novel, How It All Began (2011), concludes: "What we add up to, in the end, is a handful of images, apparently unrelated and unselected. Chaos, you would think, except that it is the chaos that makes each of us a person. Identity, it is called in professional speak" (203). Reviewing Ammonites and Leaping Fish, Rachel Cooke suggested that the book appears to be "less of a memoir than a ledger on which its author has noted some of the objects and memories that, in this final stage of life, continue to tether her to the world that made her" (Cooke 2013).

In a remark that in fact pertains to all of Lively's autobiographies, Connolly says of $A$ House Unlocked that, despite the undeniable tone of nostalgia in her journey to the past, "Change [...] is something to be explored, not rued" (Connolly 2001). Private memory sustains her and ensures her a sense of identity; however, collective memory, even if tangentially linked to historical narratives, connects her to a broader context and, while eroding the importance of her individual life, absorbs the ageing writer into "an unstoppable progress, the march of time, everything going on everywhere," making her a part of global history (Lively 2014: 91-92). While keeping in sight the ongoing narrative of public history, Lively prefers to explore and cherish her own past in the form of a private collection of artefacts. By adroitly negotiating a path between memory as a repository of personal experiences and its capacity for collective narrativisation, Lively takes advantage of (and takes comfort in) both approaches.

\section{Notes}

$1 \quad$ Her first book for adults was not a novel but an introduction to landscape history called The Presence of the Past (1976). The title, as Kerstin Ebel argues in her overview of Lively's oeuvre, "already neatly encapsulates almost all of the writer's later concerns and arguments" (2004: 351). Ebel observes that her characters not only remember incidents from the past but also reflect on the workings of memory (43). Despite Lively's claim that her novels are not autobiographical, one may detect certain parallels between her own experiences and memories, and her characters' lives (cf. Ebel 2004: 2).

2 However, as Frans Blom argues, Lively's determination to convey her opinions to her readers may occasionally be seen as excessive and detrimental to the quality of her fiction: "A problem with quite a few of her novels is that they are brimful of theories and ideas which are sometimes superimposed upon her fiction. The author's comments become too dominant and the story too schematic" (1997: 241).

3 The book was published in the United States under the title Dancing Fish and Ammonites: A Memoir.

$4 \quad$ This is a term she borrows from Sir Thomas Browne's Hydrotaphia, Urne-Buriall (Lively 2014: 42). The title of her novel Treasures of Time also comes from Browne's work.

$5 \quad$ Socrates in Theaetetus: "Imagine, then, for the sake of argument, that our minds contain a block of wax [...]. Let us call it the gift of the Muses' mother, Memory, and say that whenever we wish to remember something we see or hear or conceive in our own minds, we hold this wax under the perceptions or ideas and imprint them on it as we might stamp the impression of a seal-ring" (Plato 1935: 121).

6 Claudia, the narrator-protagonist in Moon Tiger (who, incidentally, was in Egypt during the 
Second World War, like Lively herself), clearly voices the author's own views in saying: "I am composed of a myriad Claudias who spin and mix and part like sparks of sunlight on water" (1987: 2). Tony E. Jackson claims that Claudia's idea of self is derived from the belief that "who we are at a given period of time depends upon the particular arrangement of our collection of memories" rather than sequential accumulation (1999: 175).

$7 \quad$ Lively has also produced a fictitious autobiography called Making It Up (2005), which is grounded in the fantasy that her life at some point had taken an alternative direction. Sarah Crown comments that "she approaches her personal history rather as one of the archaeologists who populate her work might approach unearthed artefacts: turning her life's chief junctures over in her hands, and exploring the possibilities they represent" (in Lively 2009).

8 The reference is to Vladimir Nabokov's Speak, Memory: An Autobiography Revisited (1989).

$9 \quad$ Likewise, in De oratore Cicero underlines that the art of memory depends on one's ability to create a proper locality and subsequently place in it mental images representing the content one wishes to store in memory (Cicero 2007: 40). In Institutio oratoria Quintilian further elaborates the "rules for places," giving clear instructions about how to move around imaginary buildings in order to call up associations in memory (Yates 1999: 38). The Art of Memory (first published in 1966).

\section{References}

Blom, Frans (1997) 'The Novels of Penelope Lively.' In: Mazur, Zygmunt and Teresa Bela (eds.) New Developments in English and American Studies: Continuity and Change. Proceedings of the Seventh International Conference on English and American Literature and Language. Kraków, March 27-29, 1996. Kraków: Universitas, 237-248.

Cicero (2007) 'From On the Ideal Orator (De oratore).' In: Rossington, Michael and Anne Whitehead (eds.) Theories of Memory. A Reader. Edinburgh: Edinburgh University Press, 39-42.

Connolly, Cressida (2001) 'So Many Rooms - But No Room for Sentiment: A House Unlocked, Penelope Lively.' The Observer, 26 August. http://www.theguardian.com/books/2001/aug/26/ biography.features1 (accessed 5 September 2016).

Cooke, Rachel (2013) 'Ammonites \& Leaping Fish: A Life in Time by Penelope Lively - review.' The Observer, 20 October. https://www.theguardian.com/books/2013/oct/20/ammonites-fishpenelope-lively-review (accessed on 5 September 2016).

Ebel, Kerstin (2004) '... Something that People Can't Do Without': The Concepts of Memory and the Past in the Work of Penelope Lively and Other Contemporary British Writers. Heidelberg: Universitätsverlag Winter.

Freud, Sigmund (1959) 'A Note upon the 'Mystic Writing Pad.' In: Strachey, James (ed.) Sigmund Freud, Collected Papers. Vol. V. New York: Basic Books, 175-180.

Gudmundsdóttir, Gunnthórunn (2003) Borderlines: Autobiography and Fiction in Life Writing. Amsterdam: Brill Academic Publishers.

Jackson, Tony E. (1999) 'The Desires of History, Old and New.' CLIO: A Journal of Literature, History, and the Philosophy of History 28(2), 169-187.

Kalaga, Wojciech (2012) 'Pamięć, interpretacja, tożsamość' [Memory, interpretation, identity]. Teksty Drugie 1-2, 39-58.

King, Nicola (2000) Memory, Narrative, Identity: Remembering the Self. Edinburgh: Edinburgh University Press.

Krell, David Farrell (1990) Of Memory, Reminiscence and Writing: On the Verge. Bloomington: Indiana University Press.

Lively, Penelope (1981) 'Bones in the Sand.' The Horn Book 57(6), 641-651.

Lively, Penelope (1985) According to Mark. Harmondsworth: Penguin.

Lively, Penelope (1987) Moon Tiger. New York: Harper and Row.

Lively, Penelope (1995) [1994] Oleander, Jacaranda: A Childhood Perceived. London: Penguin Books. 
Lively, Penelope (2001) A House Unlocked. London: Viking.

Lively, Penelope (2009) 'A Life in Books: Penelope Lively.' Interview by Sarah Crown. The Guardian, 25 July. http://www.theguardian.com/books/2009/jul/25/life-books-penelope-livelyinterview (accessed on 13 September 2016).

Lively, Penelope (2012) [2011] How It All Began. London: Penguin.

Lively, Penelope (2014) [2013]. Ammonites and Leaping Fish: A Life in Time. London: Penguin Books.

Locke, John (1894) An Essay Concerning Human Understanding. Vol. 1. Collated and annot., with prolegomena, biogr., crit., and historical by Alexander Campbell Fraser. Oxford: Clarendon Press.

McAlpin, Heller (2014) 'Dancing Fish and Ammonites: A Memoir by Penelope Lively.' The Washington Post, $14 \mathrm{Feb}$. https://www.washingtonpost.com/opinions/dancing-fish-and-ammonitesa-memoir-by-penelope-lively/2014/02/14/9a3510e6-8529-11e3-bbe5-6a2a3141e3a9_story.html (accessed on 12 September 2016).

Mezei, Kathy (2005) 'Domestic Space and the Idea of Home in Auto/Biographical Practices.' In: Kadar, Marlene, Linda Warley, Jeanne Perreault and Susanna Egan (eds.) Tracing the Autobiographical. Waterloo, ON: Wilfrid Laurier University Press, 81-95.

Parker, Peter (2013) 'Ammonites and Leaping Fish, by Penelope Lively, review.' The Telegraph, 21 October. http://www.telegraph.co.uk/culture/books/bookreviews/10386510/Ammonites-andLeaping-Fish-by-Penelope-Lively-review.html (accessed on 12 September 2016)

Plato (1935) Plato's Theory of Knowledge: The Theaetetus and the Sophist of Plato. Transl. with a running comment. by Francis Macdonald Cornford. London: Kegan Paul, Trench, Trubner \& Co. LTD.; New York: Harcourt, Brace and Company.

Richards, Jennifer (2007) Introduction. 'Classical and Early Modern Ideas of Memory.' In: Rossington, Michael and Anne Whitehead (eds.) Theories of Memory. A Reader. Edinburgh: Edinburgh University Press, 19-24.

Ricoeur, Paul (1991) 'Narrative Identity.' Philosophy Today 35(1), 73-81.

Rossington, Michael and Anne Whitehead (eds.) (2007) Theories of Memory. A Reader. Edinburgh: Edinburgh University Press.

Tonkin, Boyd (2013) 'Ammonites and Leaping Fish: A Life in Time by Penelope Lively.' The Independent, 25 October. http://www.independent.co.uk/arts-entertainment/books/reviews/bookreview-ammonites-leaping-fish-a-life-in-time-by-penelope-lively-8901977.html (accessed on 12 September 2016).

Traugott, Maggie (1994) 'That Egyptian Mummy: Oleander, Jacaranda, Penelope Lively.' The Independent, 22 May. http://www.independent.co.uk/arts-entertainment/book-review-that-egyptian-mummy-oleander-jacaranda-penelope-lively-viking-14-pounds-1437668.html (accessed on 12 September 2016).

Yates, Frances A. (1999) [1966] The Art of Memory. London: Pimlico.

Bożena KuCAŁA, Dr hab., teaches nineteenth-century and contemporary English literature at the Institute of English Studies of the Jagiellonian University in Kraków. Her academic interests include contemporary fiction, especially history and the novel and neo-Victorian fiction. Main publications: monograph: Intertextual Dialogue with the Victorian Past in the Contemporary Novel (2012); co-edited books: Writer and Time: James Joyce and After (2010), Confronting the Burden of History: Literary Representations of the Past (2012), Travelling Texts: J. M. Coetzee and Other Writers (2014), The Art of Literature, Art in Literature (2014).

Address: Bożena Kucała, Institute of English Studies, Jagiellonian University, al. Mickiewicza 9, 31-120 Kraków, Poland. [email: bozena.kucala@uj.edu.pl] 
